\title{
Genotypic and Phenotypic Analysis of $S$. mutans Isolated from Dental Biofilms Formed In Vivo Under High Cariogenic Conditions
}

\author{
Rodrigo Alex ARTHUR \\ Altair Antoninha DEL BEL CURY \\ Renata Oliveira MATTOS-GRANER \\ Pedro Luiz ROSALEN \\ Gláuber Campos VALE \\ Adriana Franco PAES LEME \\ Jaime Aparecido CURY \\ Cínthia Pereira Machado TABCHOURY
}

Piracicaba Dental School, UNICAMP - University of Campinas, Piracicaba, SP, Brazil

\begin{abstract}
The oral cavity harbors several Streptococcus mutans genotypes, which could present distinct virulence properties. However, little is known about the diversity and virulence traits of $S$. mutans genotypes isolated in vivo under controlled conditions of high cariogenic challenge. This study evaluated the genotypic diversity of $S$. mutans isolated from dental biofilms formed in vivo under sucrose exposure, as well as their acidogenicity and aciduricity. To form biofilms, subjects rinsed their mouths with distilled water or sucrose solution 8 times/day for 3 days. S. mutans collected from saliva and biofilms were genotyped by arbitrarily-primed PCR. Genotypes identified in the biofilms were evaluated regarding their ability to lower the suspension $\mathrm{pH}$ through glycolysis and their acid susceptibility and F-ATPase activity. Most subjects harbored only one genotype in saliva, which was detected in almost all biofilm samples at high proportions. Genotypes isolated only in the presence of sucrose had higher acidogenicity than those isolated only in the presence of water. Genotypes from biofilms formed with sucrose were more aciduric after 30 and $60 \mathrm{~min}$ of incubation at $\mathrm{pH} 2.8$ and 5.0, respectively. The present results suggest that biofilms formed under high cariogenic conditions may harbor more aciduric and acidogenic $S$. mutans genotypes.
\end{abstract}

Key Words: dental biofilm, genotypic diversity, Streptococcus mutans, sucrose.

\section{INTRODUCTION}

Dental caries is a dietary- and biofilm-dependent disease that is associated with the frequent consumption of fermentable carbohydrates (1) and to the shift in biofilm microbiota induced by the $\mathrm{pH}$ fall (2). Among dietary carbohydrates, sucrose is the most cariogenic because, in addition to being fermented, it is also a unique substrate for the synthesis of extracellular polysaccharide (EPS) (3), which improves bacterial adherence to tooth surfaces and modifies the matrix of dental biofilms (4).

Among the cariogenic microorganisms that colonize dental biofilms, mutans streptococci (MS), especially Streptococcus mutans (5), is the most implicated in dental caries. S. mutans produce EPS from sucrose and are acidogenic and aciduric, that is, they metabolize fermentable carbohydrates, producing acids that decrease the $\mathrm{pH}$ of the biofilm and have the ability to survive, grow and maintain their metabolism under acidic conditions (2). Their ability to tolerate acid is partly due to a membrane-bound protein called F-ATPase, which extrudes protons out of the cells, preventing a decrease in the intracellular $\mathrm{pH}$ and consequent damage to acidsensitive enzymes, DNA and proteins (6).

Several studies have shown that the oral cavity harbors distinct $S$. mutans genotypes in the saliva and dental biofilms (7-10). Additionally, it has been shown that genotypes could differ in virulence (8), which may change their ability to colonize and predominate 
in a specific environment. In an environment of high cariogenicity, S. mutans genotypes could present virulence traits that could increase the capacity of this microorganism of colonizing the oral cavity. However, little is known about the genotypic diversity and phenotypic traits of $S$. mutans isolated from dental biofilms formed in vivo under conditions of frequent and controlled exposure to sucrose.

This study sought to evaluate the genotypic diversity and the virulence traits related to the acidogenicity and aciduricity of $S$. mutans isolated from dental biofilms formed in vivo under conditions of high cariogenic challenge (i.e., biofilm accumulation under frequent exposure to sucrose).

\section{MATERIAL AND METHODS}

\section{Subjects and Study Design}

This crossover study was approved by the Ethics Committee of Piracicaba Dental School (protocol number 053/2004 and 004/2006). Twelve healthy adults, after signing an informed consent, were screened for their salivary levels of MS. From this group of subjects, a subset of 6 subjects (18 to 28 years old) with normal salivary flow (mean: $1.5 \mathrm{~mL} / \mathrm{min}$ ) were selected for their high MS counts in saliva $\left(\geq 10^{5}\right.$ colonies forming units per milliliter - CFU/mL) and ability to comply with the experimental protocol. Subjects were excluded from the study if they had used antibiotics for the last 2 months before starting the study, used any form of medication that modifies salivary secretion, used fixed or removable orthodontic appliances or had periodontal disease or general/systemic illness. In 2 experimental phases, subjects rinsed their mouths with distilled, deionized water or a solution of $20 \%$ sucrose 8 times a day. Dental biofilms that formed in vivo with water or sucrose on the smooth surfaces of the upper pre-molars and molars were collected for analysis of the genotypic diversity of $S$. mutans arbitrarily primed polymerase chain reaction (AP-PCR). Afterwards, all the $S$. mutans genotypes identified in the biofilms were phenotypically evaluated according to their acidogenicity (ability to lower the $\mathrm{pH}$ through glycolysis) and aciduricity (acid susceptibility and F-ATPase activity).

\section{Saliva Sampling and Microbiological Analysis}

Stimulated whole saliva samples were collected from the subjects in the morning, under fasting conditions and without previous toothbrushing. The saliva was diluted in sterile $0.9 \% \mathrm{NaCl}$ and inoculated in triplicate onto Mitis Salivarius Agar (MSA) (Difco, Sparks, MD, USA) plates supplemented with 20\% sucrose (Merck, Darmstadt, Germany) and $0.2 \mathrm{U} / \mathrm{mL}$ of bacitracin (Sigma, Steinheim, Germany) (MSB). The plates were incubated at $37^{\circ} \mathrm{C}$ for $48 \mathrm{~h}$ in an atmosphere of $10 \% \mathrm{CO}_{2}$. Eight colonies, which exhibited morphology consistent with $S$. mutans, were randomly collected from the MSB plates and subcultured first on MSA and then on Brain Heart Infusion (BHI) agar (Difco). Pure cultures, evaluated by Gram's staining and colony morphology on MSA, were stored in 10\% skim milk medium (Difco) at $-70^{\circ} \mathrm{C}$ for further genotypic analysis (7).

\section{In Vivo Biofilm Formation and Collection}

An in vivo crossover study was conducted in 2 phases of 3 days each. During each phase, the 6 selected subjects rinsed their mouths with $15 \mathrm{~mL}$ of distilled, deionized water or a solution of $20 \%$ sucrose for $10 \mathrm{~s}$, 8 times a day, at predetermined times (11). During this time, the subjects were instructed to neither brush the upper pre-molars and molars nor use dental floss on these teeth to allow for the accumulation of the biofilms. A wash-out period of 15 days was carried out between both phases (7) to eliminate any possible residual effects from the treatments. The distilled, deionized water and sucrose solutions were provided daily to the subjects.

At the end of each 3-day experimental phase, 10 $\mathrm{h}$ after the last exposure to the respective solution, the biofilms that formed on the smooth surfaces of the upper pre-molars and molars were collected using a sterile spatula. The collection was performed in the morning, under fasting conditions and without teeth brushing. The biofilm was weighed $( \pm 0.01 \mathrm{mg})$, suspended in sterile $0.9 \% \mathrm{NaCl}$ solution ( $1 \mathrm{~mL} / \mathrm{mg}$ wet weight), sonicated, serially diluted in saline solution and inoculated in duplicate on MSB plates. The plates were incubated at $37^{\circ} \mathrm{C}$ for $48 \mathrm{~h}$ in an atmosphere of $10 \% \mathrm{CO}_{2}$. Then seven to eight colonies morphologically consistent with being $S$. mutans were randomly collected and frozen as described above for the saliva samples.

At the end of each experimental phase, all the subjects underwent professional dental prophylaxis. The examiners analyzed the coded samples in a blinded fashion; the subjects were able to identify the treatments by the flavor of the solutions. 


\section{Extraction of Genomic DNA from S. mutans Strains}

Frozen aliquots of each colony isolated either from saliva or dental biofilms were grown on BHI agar (Difco) and incubated at $37^{\circ} \mathrm{C}$ for $24 \mathrm{~h}$ in an atmosphere of $10 \% \mathrm{CO}_{2}$. The colonies that grew on $\mathrm{BHI}$ agar were inoculated into Todd Hewitt Broth (Difco) and incubated at $37^{\circ} \mathrm{C}$ for $18 \mathrm{~h}$ in an atmosphere of $10 \% \mathrm{CO}_{2}$. Cells from these cultures were then harvested, and genomic DNA was extracted from the cell pellet (7). The integrity of the genomic DNA was evaluated by electrophoresis on 1\% agarose gels (Invitrogen, Barcelona, Spain) using a 1-kbp DNA ladder (Invitrogen). The gels were then stained with $5 \mu \mathrm{g} / \mathrm{mL}$ ethidium bromide to visualize the DNA bands. PCR with species-specific primers to the $g t f \mathrm{~B}$ (5'-ACTACACTTTCGGGTGGCTTGG-3' and 5'-CAGTATAAGCGCCAGTTTCATC-3') and $g b p \mathrm{~B}$ (5'-CAACAGAAGCACAACCATCA-3' and 5'-TGTCCACCATTACCCCAGT-3') genes was performed to confirm the identity of the $S$. mutans isolates $(8,12)$.

\section{Genotypic Analysis}

AP-PCR assays were performed using the OPA 02 primer $\left(5^{\prime}\right.$-TGCCGAGCTG-3') $(7,10)$. The amplifications were performed under the following conditions: $95^{\circ} \mathrm{C}$ for $2 \mathrm{~min}, 45$ cycles of $94^{\circ} \mathrm{C}$ for $30 \mathrm{~s}$, $36^{\circ} \mathrm{C}$ for $30 \mathrm{~s}$ and $72^{\circ} \mathrm{C}$ for $1 \mathrm{~min}$ and extension at $72^{\circ} \mathrm{C}$ for $5 \mathrm{~min}$. As positive and negative PCR controls, we used genomic DNA from $S$. mutans strain UA 130 and distilled, deionized water, respectively. The AP-PCR products were electrophoretically resolved on $1.5 \%$ agarose gels at $3 \mathrm{~V} / \mathrm{cm}$ for $3 \mathrm{~h}$ in Tris-borate-EDTA buffer (pH 8.0) using a 250-bp DNA ladder (Invitrogen). The gels were stained with $5 \mu \mathrm{g} / \mathrm{mL}$ ethidium bromide (Invitrogen, Carlsbad, CA, USA) for $10 \mathrm{~min}$, and images were captured using a digital imaging system (Gel logic 100 Imaging System; Kodak, Japan).

For analysis of the $S$. mutans genotypic profiles from the same subject, the AP-PCR products of the isolates obtained from saliva and dental biofilms were electrophoretically resolved side-by-side in the same gel for visual comparison (7). Thus, samples representative of each genotype were re-run side-by-side in a subsequent gel to directly compare the genotypes identified within distinct saliva or biofilm samples. All the gels were evaluated by 4 different researchers who had to come to agreement on the similarities or differences among the genotyping profiles. The $S$. mutans genotypes identified were descriptively analyzed, and their proportions with respect to the number of colonies isolated from each sample and condition were calculated.

\section{Phenotypic Analysis}

Frozen stocks of all the $S$. mutans genotypes identified in the dental biofilms were grown on BHI agar plates and incubated at $37^{\circ} \mathrm{C}$ for $48 \mathrm{~h}$ in an atmosphere of $10 \% \mathrm{CO}_{2}$. Then 20 to $30 \mathrm{CFUs}$ were inoculated into $\mathrm{BHI}$ broth and incubated at $37^{\circ} \mathrm{C}$ for $18 \mathrm{~h}$ in an atmosphere of $10 \% \mathrm{CO}_{2}$.

To evaluate the ability of $S$. mutans genotypes to lower the suspension $\mathrm{pH}$ through glycolysis (13), $10^{8}$ $\mathrm{CFU} / \mathrm{mL}$-aliquots of cultures grown for $18 \mathrm{~h}$ in BHI broth were centrifuged and resuspended in $50 \mathrm{mM} \mathrm{KCl}$ supplemented with $1 \mathrm{mM} \mathrm{MgCl}{ }_{2}$ (Fluka, Steinheim, Germany). The $\mathrm{pH}$ of the solution was adjusted to 7.2, and glucose was added to a final concentration of 55.6 $\mathrm{mM}$. The decrease in $\mathrm{pH}$ was then assessed during 180 min using a glass electrode previously calibrated with $\mathrm{pH}$ standards ( $\mathrm{pH} 4.0$ and 7.0). We then determined the area under the curve (AUC) for the drop in $\mathrm{pH}$ after 180 min considering $\mathrm{pH} 3.0$ as a cut-off point. The $\mathrm{pH}$ data were converted into hydrogen ion concentration $\left(\mathrm{cH}^{+}\right)$ units, and the $\mathrm{cH}^{+}$area between time 0 and 15 min or between time 0 and 180 min was calculated using $\mathrm{pH}$ Plaque software (14). The acidogenicity was expressed as the AUC, final $\mathrm{pH}$ after $180 \mathrm{~min}$ and $\mathrm{cH}^{+}$area after 15 and $180 \mathrm{~min}$.

The ability of $S$. mutans genotypes to withstand acid challenge was evaluated using the acid killing assay (8). Briefly, $10^{8} \mathrm{CFU} / \mathrm{mL}$-aliquots of cultures grown for $18 \mathrm{~h}$ in $\mathrm{BHI}$ broth were transferred into fresh $\mathrm{BHI}$ broth and grown to mid-exponential phase $\left(\mathrm{OD}_{550}=\right.$ 0.5 ). The suspensions were then centrifuged, and the pellets were washed once with $0.1 \mathrm{M}$ glycine buffer ( $\mathrm{pH}$ 7.0) (Fluka). In addition, the washed pellets were resuspended in $0.1 \mathrm{M}$ glycine buffer $\mathrm{pH} 2.8,5.0$ and 7.0 (control). Immediately after resuspension (T0) and after $30(\mathrm{~T} 30)$ and $60(\mathrm{~T} 60) \mathrm{min}$ of incubation at $37^{\circ} \mathrm{C}$, aliquots were serially diluted in phosphate buffer $(\mathrm{pH}$ 7.2), plated on $\mathrm{BHI}$ agar and incubated at $37^{\circ} \mathrm{C}$ for $48 \mathrm{~h}$ in an atmosphere of $10 \% \mathrm{CO}_{2}$. Cell viability at each time point was expressed as the ratio between the counts of viable cells at $\mathrm{pH} 2.8$ and 5.0 and the counts of viable cells at $\mathrm{pH}$ 7.0.

For the F-ATPase assay, $10^{8} \mathrm{CFU} / \mathrm{mL}$-aliquots of 
cultures grown for $18 \mathrm{~h}$ in $\mathrm{BHI}$ broth were centrifuged and resuspended in $75 \mathrm{mM}$ Tris- $\mathrm{HCl}$ plus $10 \mathrm{mM} \mathrm{MgSO}_{4}$. The cells were then permeabilized by treatment with toluene (Merck) and subjected to several cycles of freezing and heating. The permeabilized cells were incubated with $0.5 \mathrm{M}$ adenosine 5 '-triphosphate (ATP) (Sigma) for 10 min in $50 \mathrm{mM}$ Tris-maleate buffer (pH 6.0) (Sigma) supplemented with $10 \mathrm{mM} \mathrm{MgSO}_{4}$ (Fluka) (13). The concentration of inorganic phosphorous released from ATP was determined using the method published by Bencini et al. (15). The ATPase activity was expressed as micromoles of phosphate released from ATP per gram of dry cell per minute of reaction. The standard unit of ATPase activity is $1 \mu \mathrm{mol}$ of phosphate released per min (13). All the assays described above were conducted in duplicate, 3 independent times, and the genotypes were coded. S. mutans UA 130 was used as a control.

\section{Statistical Analysis}

The data for the phenotypic traits of all the $S$. mutans genotypes isolated from the biofilms formed with water were compared with those formed with sucrose. Also, the data of phenotypic traits of genotypes exclusively isolated from biofilms formed in the absence of sucrose were compared with those isolated only from biofilms formed in the presence of this carbohydrate. The assumption of equality of variances and normal distribution of errors were checked for all the response variables tested. Data that violated these assumptions were transformed when necessary (16) and evaluated using a t-test for independent samples. When no transformation was adequate to normalize the data (ratio between counts of viable cells at pH 2.8 T30 in relation to counts at $\mathrm{pH} 7.0 \mathrm{~T} 30$ for both comparisons, AUC and $\mathrm{cH}^{+}$area after $180 \mathrm{~min}$ for the second comparison), the data were analyzed using the Wilcoxon non-parametric test. For the analysis, the SAS software system (version 8.02; SAS Institute Inc., Cary, NC, USA) was used. The significance level was set at $5 \%$ for all analyses.

\section{RESULTS}

\section{Genotypic Diversity of S. mutans Isolated from Saliva and Biofilms In Vivo}

A total of 48 colonies of $S$. mutans were isolated from saliva and 95 colonies were isolated from biofilms. All of the isolates were identified as being S. mutans by
PCR. In total, among the saliva and biofilm samples, 19 distinct genotypes were identified (Table 1). In the saliva samples of 5 subjects, only one $S$. mutans genotype was identified in each subject, whereas in another subject (subject B), two genotypes were detected in saliva (Table 1). All genotypes identified in the saliva samples were also detected in the biofilm samples of the respective subject, independently of how the biofilm was formed. One exception for this observation was subject $F$, whose salivary genotype was not identified in the biofilm formed in the absence of sucrose.

Other genotypes, in addition to those found in the saliva samples, were found in the biofilms formed with water (8 genotypes: $4 \mathrm{ddw}, 6 \mathrm{ddw}, 9 \mathrm{ddw}, 15 \mathrm{ddw}, 16 \mathrm{ddw}$, $17 \mathrm{ddw}, 18 \mathrm{ddw}$ and $19 \mathrm{ddw}$ ) and sucrose (4 genotypes: $7 \mathrm{su}$, $10 \mathrm{su}, 11 \mathrm{su}$ and $13 \mathrm{su})$. However, these genotypes were always found in lower proportion (12.5\%) compared with the genotypes also found in saliva (Table 1).

The AP-PCR genotypic profiles obtained from

Table 1. Genotypic diversity of S. mutans in saliva and in vivo dental biofilms formed with water or sucrose.

\begin{tabular}{|c|c|c|c|}
\hline \multirow{2}{*}{ Subject } & \multirow{2}{*}{ Saliva } & \multicolumn{2}{|c|}{ Biofilm formation } \\
\hline & & Water & Sucrose \\
\hline A & $1 \mathrm{sa}(100)$ & $1 \mathrm{ddw}(100)$ & 1 su (100) \\
\hline B & $\begin{array}{l}2 \mathrm{sa}(85.7) \\
3 \mathrm{sa}(14.3)\end{array}$ & $\begin{array}{l}2 \mathrm{ddw}(87.5) \\
4 \mathrm{ddw}(12.5)\end{array}$ & $2 \mathrm{su}(100)$ \\
\hline $\mathrm{C}$ & $5 \mathrm{sa}(100)$ & $\begin{array}{l}5 \mathrm{ddw}(87.5) \\
6 \mathrm{ddw}(12.5)\end{array}$ & $\begin{array}{l}5 \mathrm{su}(87.5) \\
7 \mathrm{su}(12.5)\end{array}$ \\
\hline $\mathrm{D}$ & 8 sa (100) & $\begin{array}{l}\text { 8ddw (87.5) } \\
\text { 9ddw (12.5) }\end{array}$ & $\begin{array}{c}8 \mathrm{su}(75) \\
10 \mathrm{su}(12.5) \\
11 \mathrm{su}(12.5)\end{array}$ \\
\hline E & $12 \mathrm{sa}(100)$ & $12 \mathrm{ddw}(100)$ & $\begin{array}{l}12 \mathrm{su}(87.5) \\
13 \mathrm{su}(12.5)\end{array}$ \\
\hline $\mathrm{F}$ & $14 \mathrm{sa}(100)$ & $\begin{array}{c}\text { 15ddw (50) } \\
16 \mathrm{ddw}(12.5) \\
17 \mathrm{ddw}(12.5) \\
18 \mathrm{ddw}(12.5) \\
19 \mathrm{ddw}(12.5)\end{array}$ & $14 \mathrm{su}(100)$ \\
\hline
\end{tabular}

The values with the lowercase letters indicate the genotypes (the same number represents identical genotypes). The numbers in parentheses indicate the percentage of each genotype in relation to the total number of isolated colonies. sa: genotypes isolated from saliva; ddw: genotypes isolated from biofilms formed in vivo with water; su: genotypes isolated from biofilms formed in vivo with sucrose. 
subject $\mathrm{F}$ are depicted in Figure 1.

\section{Phenotypic Characteristics}

No significant differences in acidogenicity traits were observed between the $S$. mutans genotypes isolated from biofilms formed with water or sucrose (Table 2). Genotypes exclusively found in biofilms formed with sucrose $(7 \mathrm{su}, 10 \mathrm{su}, 11 \mathrm{su}$ and $13 \mathrm{su})$ showed a lower final $\mathrm{pH}(\mathrm{p}<0.05)$ and higher $\mathrm{cH}^{+}$area after $15 \min (\mathrm{p}<0.01)$ than those found exclusively in biofilms formed with water (4ddw, 6ddw, 9ddw, 15ddw, 16ddw, 17ddw, 18ddw and 19ddw) (Table 2). No significant differences in the AUC and $\mathrm{cH}^{+}$area after 180 min were observed between the genotypes exclusively found in biofilms formed with water or sucrose.

With respect to aciduricity traits (Table 2), all the S. mutans genotypes isolated from biofilms formed with sucrose showed significantly higher ratios of viable cell counts at pH 2.8 (T30) in relation to viable cell counts at $\mathrm{pH} 7.0$ (T30) when compared with genotypes isolated from biofilms formed with water $(\mathrm{p}<0.05)$ (Table 2). However, no significant differences in aciduricity for the other time points and $\mathrm{pH}$ values or F-ATPase activity were observed. In addition, a statistically higher ratio of viable cell counts at $\mathrm{pH} 5.0$ (T60) in relation to viable cell counts at pH 7.0 (T60) was found for genotypes exclusively isolated from biofilms formed with sucrose. Furthermore, no significant differences were found in F-ATPase activity between the genotypes isolated from biofilms formed with water or sucrose $(p=0.06)$ (Table 2$)$.

\section{DISCUSSION}

The present analysis of the genotypic diversity of S. mutans revealed that most of the subjects harbored only one genotype in saliva, which was also identified in the biofilms, as previously described by others $(7,8)$ (Table 1). Although a previous study reported that saliva does not harbor all the bacterial genotypes present in the oral cavity (9), there is evidence that indicates a positive correlation between MS in saliva and those present in dental biofilms (17). Additionally, it is likely that the genotypes present in saliva reflect, at least in part, those present at higher proportions in dental biofilms, as observed in this study and by previous ones $(7,8)$.

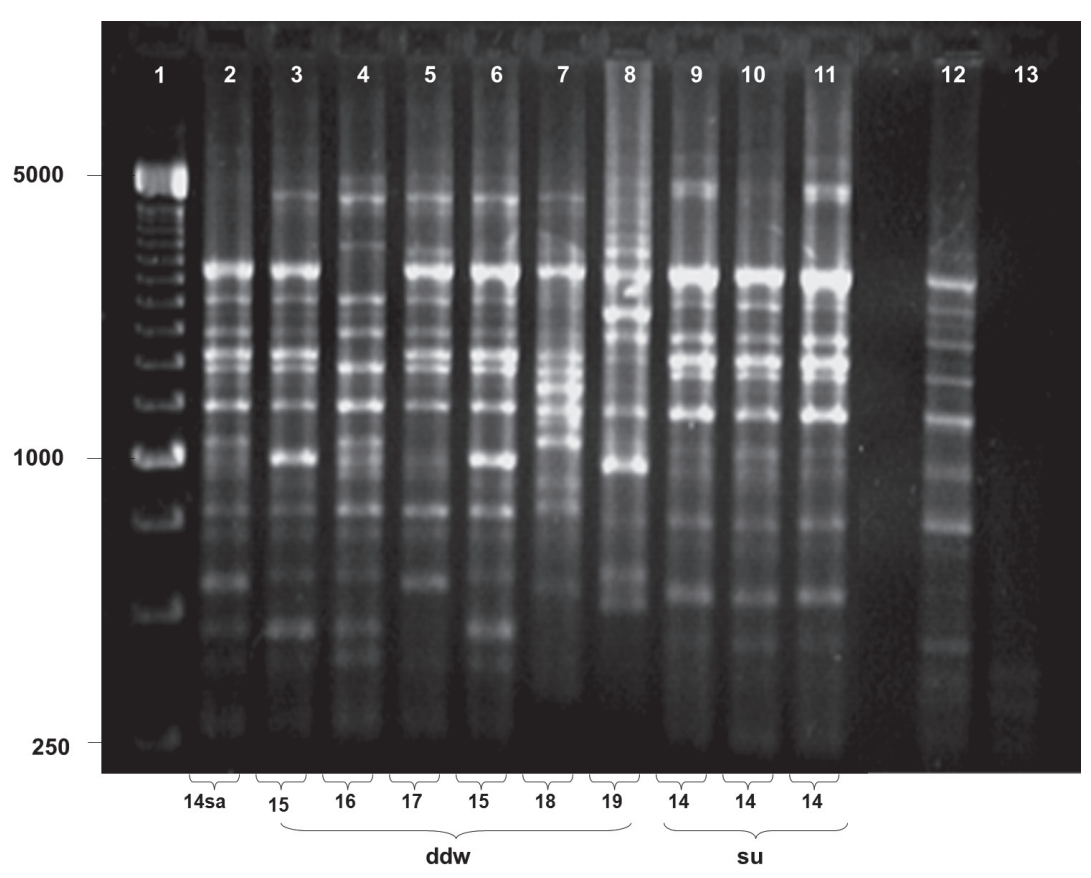

Figure 1. Agarose gel (1.5\%) showing the AP-PCR profiles of representative strains of $S$. mutans isolated from the saliva and biofilms of subject F. A 250-bp DNA ladder is shown in lane 1; lane 2 corresponds to the $S$. mutans genotype present in saliva; lanes 3 to 11 correspond to different isolates of $S$. mutans isolated from biofilms formed with water or sucrose; lanes 12 and 13 correspond to the positive control (S. mutans UA 130) and negative control (water), respectively. The numbers of the genotypes and the conditions of biofilm formation are shown at the bottom of the image. ddw: biofilms formed with water; su: biofilms formed with sucrose. 
The data obtained in the present study also suggest that there are no differences in genotypic diversity between biofilms formed with water or sucrose in vivo. In addition, our data do not support the hypothesis that frequent exposure to fermentable carbohydrate and the concomitant decrease in $\mathrm{pH}$ associated with this exposure is associated with the increased genotypic diversity of microorganisms present in the oral cavity, as has been suggested (18). However, it is difficult to directly compare the present findings with those of previous study because the experimental conditions used, including the short period of biofilm accumulation of our study and the formation of biofilms in response to sucrose, were different. Nevertheless, despite the lack of differences in genotypic diversity between $S$. mutans isolated from biofilms formed with water or sucrose, both conditions of biofilm formation allowed additional genotypes, other than those detected in saliva, to be isolated from the biofilms formed in vivo, albeit in lower proportions (Table 1). These findings are in agreement with those of previous report (7). These particular genotypes may be present in saliva at levels below the limit of detection of the microbiological method used (9), and the specific conditions of the biofilm community that we evaluated might have improved their colonization and, consequently, influenced the proportions of these

Table 2. Acidogenicity traits, cell viability at $\mathrm{pH} 2.8$ and 5.0 (ratio in relation to cell viability at $\mathrm{pH} 7.0$ for each time point) and F-ATPase activity of the $S$. mutans genotypes isolated from biofilms formed in vivo (mean $\pm \mathrm{sd}$ ).

\begin{tabular}{|c|c|c|c|c|}
\hline \multirow{3}{*}{ Analysis } & \multicolumn{4}{|c|}{ Comparison } \\
\hline & \multicolumn{2}{|c|}{ All genotypes isolated from biofilms ${ }^{£}$} & \multicolumn{2}{|c|}{ Genotypes isolated exclusively from biofilms ${ }^{\psi}$} \\
\hline & $\begin{array}{l}\text { Water } \\
(n=13)\end{array}$ & $\begin{array}{l}\text { Sucrose } \\
(\mathrm{n}=10)\end{array}$ & $\begin{array}{l}\text { Water } \\
(\mathrm{n}=8)\end{array}$ & $\begin{array}{l}\text { Sucrose } \\
(n=4)\end{array}$ \\
\hline \multicolumn{5}{|l|}{ Acidogenicity } \\
\hline $\begin{array}{l}\text { AUC } \\
\text { (after } 180 \mathrm{~min} ; \mathrm{min} * \mathrm{pH})\end{array}$ & $315.0 \pm 58.7^{\#}$ & $321.2 \pm 105.5^{\#}$ & $298.1 \pm 17.0$ & $295.0 \pm 13.1$ \\
\hline $\begin{array}{l}\text { Final pH } \\
\text { (after } 180 \mathrm{~min})\end{array}$ & $4.0 \pm 0.1$ & $3.9 \pm 0.2$ & $3.9 \pm 0.06^{\mathrm{A}}$ & $3.7 \pm 0.1^{\mathrm{B}}(\mathrm{n}=3)^{*}$ \\
\hline $\begin{array}{l}\mathrm{cH}^{+} \text {area } \\
(\text { after } 15 \mathrm{~min} ; \mu \mathrm{mol} / 1 / \mathrm{min})\end{array}$ & $0.3 \pm 0.1^{\S}$ & $0.8 \pm 1.3^{\S}$ & $0.4 \pm 0.1^{\mathrm{B} \S}$ & $2.3 \pm 0.9^{\mathrm{A} \S}(\mathrm{n}=3)^{*}$ \\
\hline $\begin{array}{l}\mathrm{cH}^{+} \text {area } \\
(\text { after } 180 \mathrm{~min} ; \mu \mathrm{mol} / 1 / \mathrm{min})\end{array}$ & $131.8 \pm 58.7$ & $147.2 \pm 60.9$ & $139.5 \pm 16.2$ & $167.6 \pm 77.2$ \\
\hline \multicolumn{5}{|l|}{ Aciduricity } \\
\hline $\mathrm{pH} 2.8 * * \mathrm{~T} 0$ & $1.0 \pm 0.4$ & $1.2 \pm 0.6$ & $0.9 \pm 0.5$ & $1.3 \pm 0.2$ \\
\hline $\mathrm{pH} 2.8 \mathrm{~T} 30\left(\mathrm{x} 10^{-2}\right)$ & $0.03 \pm 0.09^{\mathrm{B}}$ & $0.1 \pm 0.2^{\mathrm{A}}$ & $0.0 \pm 0.0$ & $0.04 \pm 0.05$ \\
\hline $\mathrm{pH} 5.0 \mathrm{T0}$ & $1.1 \pm 0.3$ & $1.1 \pm 0.2$ & $1.0 \pm 0.2$ & $1.2 \pm 0.04$ \\
\hline pH 5.0 T30 & $1.1 \pm 0.4 \S$ & $1.2 \pm 0.6^{\S}$ & $1.0 \pm 0.4 \S$ & $1.0 \pm 0.2^{\S}$ \\
\hline pH 5.0 T60 & $0.9 \pm 0.3^{\S}$ & $1.0 \pm 0.2^{\S}$ & $0.8 \pm 0.2^{\mathrm{B}}$ & $1.1 \pm 0.2^{\mathrm{A}}$ \\
\hline $\begin{array}{l}\text { F-ATPase activity } \\
(\mu \mathrm{mol} / \mathrm{g} / \mathrm{min})\end{array}$ & $16.1 \pm 8.5$ & $25.1 \pm 13.8$ & $15.9 \pm 8.6$ & $23.7 \pm 15.1$ \\
\hline
\end{tabular}

$£$ All the S. mutans genotypes isolated from the biofilms formed with water were compared with those formed with sucrose. $\psi$ Genotypes exclusively isolated from biofilms formed in the absence of sucrose were compared with those isolated only from biofilms formed in the presence of this carbohydrate. Means for each type of comparison that are followed by distinct letters differ statistically $(\mathrm{p}<0.05)$; those that are not followed by letters do not differ from each other. AUC: Area under the curve for the drop in $\mathrm{pH}$ fall; $\mathrm{cH}+$ : hydrogen ion concentration. \# data transformed by $1 / \mathrm{AUC}$; §data transformed by $\log 10 .{ }^{*}$ The $\mathrm{n}$-value is different due to the exclusion of outliers from the genotype $13 \mathrm{su}$ (values of 4.22 for final $\mathrm{pH}$ and 0.10 for $\mathrm{cH}+$ area after $15 \mathrm{~min}$ ). **All genotypes showed counts of viable cells below the detection limit at $60 \mathrm{~min}$ after resuspension in glycine buffer $\mathrm{pH} 2.8$. 


\section{S. mutans genotypes.}

In relation to the phenotypic traits, $S$. mutans genotypes isolated exclusively from biofilms formed with sucrose (7su, 10su, 11su and $13 \mathrm{su}$ ) were more acidogenic according to the $\mathrm{cH}^{+}$area after 15 min and final $\mathrm{pH}$ than those isolated exclusively from biofilms formed with water (4ddw, $6 \mathrm{ddw}, 9 \mathrm{ddw}, 15 \mathrm{ddw}, 16 \mathrm{ddw}$, $17 \mathrm{ddw}, 18 \mathrm{ddw}$ and $19 \mathrm{ddw}$ ) (Table 2). Because these genotypes were the least prevalent in sucrose-formed biofilms, we may speculate that the modifications induced by microorganisms in the biofilms and their virulence traits are more important than the relative numbers of bacteria found in the biofilms (19). Nevertheless, these findings should be interpreted with care as no significant differences were observed for the two other acidogenicity variables, AUC and $\mathrm{cH}^{+}$area after $180 \mathrm{~min}$. Further studies, with a larger number of subjects and a longer period of sucrose exposure, should be conducted.

Because the activity of the F-ATPase pump is inversely related to the environmental $\mathrm{pH}$ (13), we hypothesized that $S$. mutans genotypes isolated from biofilms formed under conditions of frequent $\mathrm{pH}$ fall due to sucrose exposure may show higher F-ATPase activity than those isolated from biofilms not exposed to sucrose. However, under the experimental conditions of the present study, the activity of F-ATPase in the genotypes isolated from biofilms formed with water or sucrose were not significantly different $(\mathrm{p}=0.06$; Table 2). It is important to note that the differences in F-ATPase activity may have been more evident if the genotypes had been previously exposed to acid challenge. Although this was not the aim of the current investigation, it is an interesting approach for evaluation in future studies. Furthermore, a previous study suggested that toluene, which is used for cell permeabilization, may inhibit the activity of F-ATPase (20). This study also suggests that toluene may induce rupture of the cell membrane, causing an outflow of ATPases found in the cytoplasm. In this scenario, the measured F-ATPase activity may be a combination of the activity of membrane-bound F-ATPase and non-specific intracellular ATPases. Such effects might have interfered with the results of the present study, eliminating any differences between the different $S$. mutans genotypes. Thus, considering these observations, it would be interesting to evaluate a modified protocol for future studies.

It is important to point out that phenotypic expression of microorganisms may have a transitory nature, especially because this feature may depend on the way in which different genotypes are subcultured in laboratory media. In order to decrease the influence of this effect on our results, all the $S$. mutans genotypes used in the experiments conducted in this study were reactivated only once for each assay from the same frozen stock. Perhaps, an evaluation of these phenotypic traits in an in vitro biofilm model may better reflect the behavior of the genotypes under conditions of stress induced by frequent $\mathrm{pH}$ fall due to sucrose exposure.

Altogether, within the limitations of this study, the present findings suggest that, although no significant differences were found in genotypic diversity between biofilms formed with water or sucrose, biofilms formed under high cariogenic conditions may harbor more acidogenic and aciduric $S$. mutans genotypes.

\section{RESUMO}

A cavidade oral apresenta vários genótipos de Streptococcus mutans, que podem possuir diferentes capacidades de virulência. Entretanto, pouco se sabe sobre a diversidade e virulência de genótipos de $S$. mutans isolados in vivo sob uma condição controlada de alto desafio cariogênico. Este estudo avaliou a diversidade genotípica de $S$. mutans identificados no biofilme dental formado in vivo na presença de sacarose, assim como a acidogenicidade e aciduricidade desses genótipos. Para possibilitar formação de biofilme, voluntários bochecharam com água destilada ou solução de sacarose $8 \mathrm{x} /$ dia durante 3 dias. $S$. mutans isolados da saliva e do biofilme dental foram genotipados por PCR com primers-arbitrários. Genótipos isolados do biofilme foram avaliados em relação à habilidade de reduzir o $\mathrm{pH}$ da suspensão devido à glicólise, em relação à susceptibilidade a ácidos e também atividade F-ATPase. A maioria dos voluntários apresentou apenas 1 genótipo na saliva, que foram detectados em quase todas as amostras de biofilme em altas proporções. Genótipos isolados somente na presença de sacarose apresentaram maior acidogenicidade do que aqueles genótipos isolados apenas na presença de água. Genótipos de biofilmes formados na presença de sacarose foram mais acidúricos após 30 e 60 min de incubação em pH 2,8 e 5,0, respectivamente. Os resultados do presente estudo sugerem que biofilmes formados sob condição de alto desafio cariogênico podem apresentar genótipos de $S$. mutans mais acidúricos e mais acidogênicos.

\section{ACKNOWLEDGEMENTS}

This study was supported by FAPESP (process \#03/10972-8, 05/03089-6 and 07/08000-9). We would like to acknowledge the subjects for their valuable participation and Dr. Page W. Caufield from New York University, who kindly provided $S$. mutans UA 130 strain.

\section{REFERENCES}

1. Bowen WH. Do we need to be concerned about dental caries in the 
coming millennium? Crit Rev Oral Biol Med 2002;13:126-131.

2. Marsh PD. Dental plaque as a biofilm: the significance of $\mathrm{pH}$ in health and caries. Compend Contin Educ Dent 2009;30:76-87.

3. Cury JA, Rebelo MAB, Del Bel Cury AA, Derbyshire MTVC, Tabchoury CPM. Biochemical composition and cariogenicity of dental plaque formed in the presence of sucrose or glucose and fructose. Caries Res 2000;34:491-497.

4. Paes Leme AF, Koo H, Belatto CM, Bedi G, Cury JA. The role of sucrose in cariogenic dental biofilm formation - new insight. J Dent Res 2006;85:878-887.

5. Tanzer JM, Livingston J, Thompson AM. The microbiology of primary dental caries in humans. J Dent Educ 2001;65:1028-1037.

6. Quivey RG, Kuhnert W, Hahn K. Genetics of acid adaptation in oral streptococci. Crit Rev Oral Biol Med 2001;12:301-314.

7. Arthur RA, Tabchoury CPM, Mattos-Graner RO, Del Bel Cury AA, Paes Leme AF, Vale GC, et al.. Genotypic diversity of S. mutans in dental biofilm formed in situ under sugar stress exposure. Braz Dent J 2007;18:185-191.

8. Lembo FL, Longo PL, Ota-Tsuzuki C, Rodrigues CRMD, Mayer MPA. Genotypic and phenotypic analysis of Streptococcus mutans from different oral cavity sites of caries-free and caries-active children. Oral Microbiol Immunol 2007;22:313-319.

9. Baca P, Castillo AM, Baca AP, Liebana MJ, Junco P, Liebana J. Genotypes of Streptococcus mutans in saliva versus dental plaque. Arch Oral Biol 2008;53:751-754.

10. Tabchoury CPM, Sousa MCK, Arthur RA, Mattos-Graner RO, Del Bel Cury AA, Cury JA. Evaluation of genotypic diversity of Streptococcus mutans using distinct arbitrary primers. J Appl Oral Sci 2008;16:403-407.

11. Koo H, Cury JA, Rosalen PL, Ambrosano GMB, Ikegaki M, Park YK. Effect of a mouthrinse containing selected propolis on 3-day dental plaque accumulation and polyssacharide formation. Caries Res 2002;36:445-448.
12. Mattos-Graner RO, Porter KA, Smith DJ, Hogosi Y, Duncan MJ. Functional analysis of glucan binding protein B from Streptococcus mutans. J Bacteriol 2006;188:3813-3825.

13. Nascimento MM, Lemos JAC, Abranches J, Goncalves RB, Burne RA. Adaptive acid tolerance response of Streptococcus sobrinus. J Bacteriol 2004;186:6383-6390.

14. Larsen MJ, Pearce EI. A computer program for correlating dental plaque $\mathrm{pH}$ values, $\mathrm{cH}^{+}$, plaque titration, critical $\mathrm{pH}$, resting $\mathrm{pH}$ and solubility of enamel apatite. Arch Oral Biol 1997;42:475-480.

15. Bencini DA, Wild JR, O'Donovan GA. Linear one-step assay for the determination of orthophosphate. Anal Biochem 1983;132:254-258

16. Box GEP, Hunter JS, Hunter WG. Statistics for experimenters: design, innovation, and discovery. $2^{\text {nd }}$ ed. New York: John Wiley \& Sons Inc; 2005.

17. Motisuki C, Lima LM, Spolidorio DM, Santos-Pinto L. Influence of sample type and collection method on Streptococcus mutans and Lactobacillus ssp counts in the oral cavity. Arch Oral Biol 2005;50:341-345.

18. Alaluusua S, Mättö J, Grönroos L, Innilä S, Torkko H, Asikanen $\mathrm{S}$, et al.. Oral colonization by more than one clonal type of mutans streptococcus in children with nursing-bottle dental caries. Arch Oral Biol 1996;41:149-154.

19. Cury JA, Francisco SB, Del Bel Cury AA, Tabchoury CPM. In situ study of sucrose exposure, mutans streptococci in dental plaque and dental caries. Braz Dent J 2001;12:101-104.

20. Thedei G, Leitão DPS, Bolean M, Paulino TP, Spadaro ACC, Ciancaglini P. Toluene permeabilization differentially affects Fand P-type ATPase activities present in the plasma membrane of Streptococcus mutans. Braz J Med Biol Res 2008;41:1047-1053.

Received April 15, 2011

Accepted June 24, 2011 